\title{
RESEARCH OF THE EFFECTS OF SHOCK AND VIBRATIONS ON THE HUMAN BODY
}

\author{
Zoran C. Petrović \\ Serbian Armed Forces, AF and AD, 204th Aviation Brigade, Batajnica, \\ Republic of Serbia \\ e-mail: pzoran.pele@gmail.com, \\ ORCID iD: (Ohttp://orcid.org/0000-0001-8053-4034
}

DOI: $10.5937 /$ vojtehg65-8870

FIELD: Mechanics, Mechanical Engineering

ARTICLE TYPE: Review Paper

ARTICLE LANGUAGE: English

\section{Summary:}

There is very little reliable information about the forces needed to cause injury to the human body. Namely, it is very difficult to obtain reliable reports about the influence of mechanical forces and the subjective reaction to these forces, mainly due to the complexity and diversity of the human body in both physical and behavioral aspects. The need for the study of physical, physiological and psychological reactions of living beings in a laboratory, under controlled conditions, has led to the development and use of specialized devices for the simulation of impact and vibrations in order to carry out experiments on humans and animals. "Anthropometric" or "anthropomorphic" dummies that simulate the basic static and dynamic properties of the human body are widely used in the study of plane and car crashes. Thus, for example, a Hybrid III dummy is used in case of a frontal crash of the car. Various research works about automotive and aviation accidents as well as experiments with both dummies and living beings show that full support to the body and limiting the movement of the limbs provide maximum protection from the forces of acceleration.

Key words: anthropometric dummy, crash, human body, vibration, shock, aircraft, accident, automobile.

\section{Introduction}

The man, as a mechanical system, is extremely complex and his mechanical properties are often subject to change. There is very little reliable information about the forces needed to cause injury to the human 
body. To avoid injuries to humans when collecting such data for the examination of mechanical damage, it is necessary to carry out experiments on animals. However, resulting data must be subjected to detailed examination to determine the extent of their applicability to humans that differ from animals not only in size but also in their anatomical and physiological structures. It is occasionally possible to obtain useful information from situations involving accidental injuries to the man; however, while injuries can often be assessed, the forces that cause such injuries cannot, so data thus obtained are rarely useful. It is also difficult to obtain reliable data on the effects of mechanical forces on various actions and subjective reactions to these forces, mainly due to a wide variation of human beings both in physical terms and in terms of their behavior. Measurements of some of the mechanical properties of the man are, however, often possible because they require only weak forces.

\section{Definitions and characterization of forces}

Forces can reach the body through gas, liquid or solid materials. They may be diffuse or concentrated in a small area. They can vary from tangential to normal, and can operate in several directions. The shape of the solid body that violates the surface of the human body is also important, as well as the position and shape of the human body. All these factors must be taken into account when considering injuries that arise from vehicle collisions, explosions, vibrations, etc. Laboratory studies often allow a fairly precise control of forces, but real situations are much more complex. Therefore, it is often very difficult to predict what will happen in a real situation on the basis of laboratory studies. Also, it is difficult to consider terrain studies without the help of laboratory studies.

The term "shock" is used in biology and medicine differently than in mechanics. Therefore, one should be careful when using this term. In this paper, the term "shock" is used in its "engineering" meaning. In essence, forces that reach the maximum value for less than a few tenths of a second and last no more than a few seconds can be considered as forces that cause a shock in the human body.

The term "impact" refers to the force applied when the human body comes into a sudden contact with a solid body and when there is a large transmission of pulses, e.g. when speed is sharply reduced in a vehicle crash or when a solid body that moves at high speed slams into the human body (Harris, Piersol, 1988). 


\section{Methods and instrumentation}

Most quantitative research works on the effects of shock and vibration on humans are performed in a laboratory under controlled simulated conditions. Significant results from these tests can be obtained only if the methods of measurement and instrumentation are adapted to the specific characteristics of biological systems under study in order to avoid the influence of the measurement on the behavior of the system. The behavior of the system can be seen in the physical, physiological and psychological sense, although these parameters, if possible, should be studied separately. The complexity of living organisms makes such consideration, even if it is assumed that the parameters are independent, only approximately accurate at best. In many cases, if not taking care while planning and leading experiments, an uncontrolled interaction of these parameters can lead to completely erroneous results. For example, the dynamic elasticity of the tissue of a specific part of the body may depend on simultaneously excited vibrations of the other parts of the body, or elasticity can be varied during measurements since the physiological response of a living organism varies, or elasticity can be influenced by psychological reactions of the living organism to the test itself or to the measurement equipment.

Control and compensation for nonuniformity of living systems is very important because of variations in size, shape, sensitivity and response of people since these factors can vary for an individual, depending on the weather, experience and motivation. Using a proper experiment project is necessary and almost always requires a large number of observations and planned controls (Harris, Piersol, 1988).

\section{Simulation of mechanical environment}

The desire to study the physical, physiological and psychological reactions of living creatures in a laboratory under well-controlled conditions has led to the use of standard and specialized devices for shock and vibration experiments on humans and animals. Some of the devices used in such tests are given in Figure 1 (Harris, Piersol, 1988).

A precise simulation of environmental conditions a man is exposed to is often not feasible for technical and economic reasons, or may even be undesirable because of the need for more systematic research under slightly simplified terms. Therefore, most studies have been limited to the study of one degree of freedom in which the man is exposed to vibrations in one direction only. For this purpose, mechanical and electrodynamic 
vibration testing tables are often used. The conditions to be satisfied by all the devices for shock (impact) and vibration testing are: adequate protective measures, secure and precise exposure control and payload equal to the total weight of the subject, seats and instrumentation.

One vertical accelerator, for example, simulates large amplitude sinusoid or random vibrations such as those encountered in accidents during high-speed flight at low altitude, or those expected in the launch and return phases of spacecraft. This device can be programmed to record acceleration achieved in real flight conditions.

\begin{tabular}{|c|c|c|c|}
\hline Type of machine & $\begin{array}{c}\text { Application } \\
\text { of force }\end{array}$ & $\begin{array}{c}\text { Frequency } \\
\text { range }\end{array}$ & Maximum amplitude \\
\hline \multirow{2}{*}{$\begin{array}{l}\text { Shake table } \\
\text { (Figure 2) }\end{array}$} & & $\begin{array}{c}\text { mechanical } \\
0-50 \mathrm{~Hz}\end{array}$ & $\begin{array}{c}\text { acceleration } \\
\text { up to } 15 \mathrm{~g}\end{array}$ \\
\hline & & $\begin{array}{c}\text { electrodynamic } \\
15-1.000 \mathrm{~Hz}\end{array}$ & \\
\hline $\begin{array}{c}\text { Vertical accelerator } \\
\text { (Figure 3) }\end{array}$ & & $0-10 \mathrm{~Hz}$ & $\begin{array}{c}\text { displacement } \pm 3 \mathrm{~m} \\
\text { acceleration } 3,7 \mathrm{~g}\end{array}$ \\
\hline Shock machine & & $\begin{array}{l}\text { Down to } \\
\mathrm{T}=0,16 \mathrm{~s}\end{array}$ & $10^{-2}$ do $10^{-1} \mathrm{~cm}$ \\
\hline $\begin{array}{l}\text { Horizontal or } \\
\text { vertical decelerator } \\
\text { or accelerator } \\
\text { (Figure 4) }\end{array}$ & & $\begin{array}{c}\text { Rate of } \\
\text { acceleration } \\
\text { up to } 1.400 \mathrm{~g} / \mathrm{s}\end{array}$ & $40 \mathrm{~g}$ peak \\
\hline $\begin{array}{c}\text { Siren } \\
\text { (airborne sound) }\end{array}$ & & $25-100.000 \mathrm{~Hz}$ & $\begin{array}{l}\text { noise } \\
160-170 \mathrm{~dB}\end{array}$ \\
\hline $\begin{array}{l}\text { Head impact machine for } \\
\text { a dummy } \\
\text { (Figure 6) }\end{array}$ & & $\begin{array}{l}\text { Depending on the } \\
\text { machine }\end{array}$ & $\begin{array}{l}\text { Impact velocity } \\
43 \mathrm{~m} / \mathrm{s}\end{array}$ \\
\hline
\end{tabular}

Figure 1 - Summary of the characteristics of shock - impact and vibration machines used for experiments on humans and animals (Frequency range and maximum amplitudes refer to the values used, not to the capabilities of such machines)

Puc. 1 - Обзор характеристик устройства для измерения ударов и вибраций, применяемых в экспериментах с участием людей и животных (диапазон частот и колебаний, относятся к используемым значениям, а не к возможностям устройства) Слика 1 - Преглед карактеристика уређаја за шок-удар и вибрације које се користе за експерименте са људима и животињама (распон фрреквенција и максималне амплитуде односе се на коришћене вредности, а не на могућности машина) 
Other machines for the study of the sensitivity threshold in the man ejected from an aircraft moving at high speed (ejection seat) have straps for upward or downward acceleration on movable seats with explosive charges.

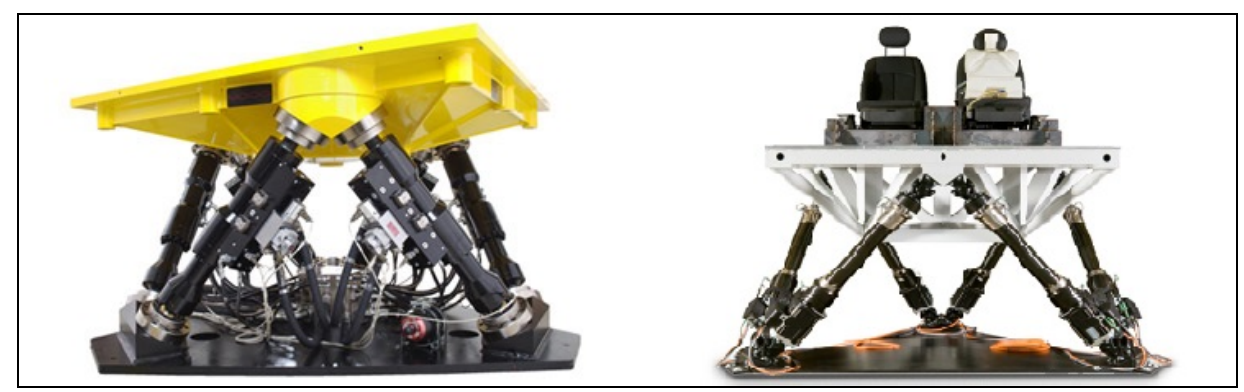

Figure 2 - Shake tables: hydraulic - left, electric - right

Puc. 2 - Вибростол : гидравлический - слева; электрический - справа

Слика 2 - Вибрациони столови: хидраулички - слика лево, електрични - слика десно

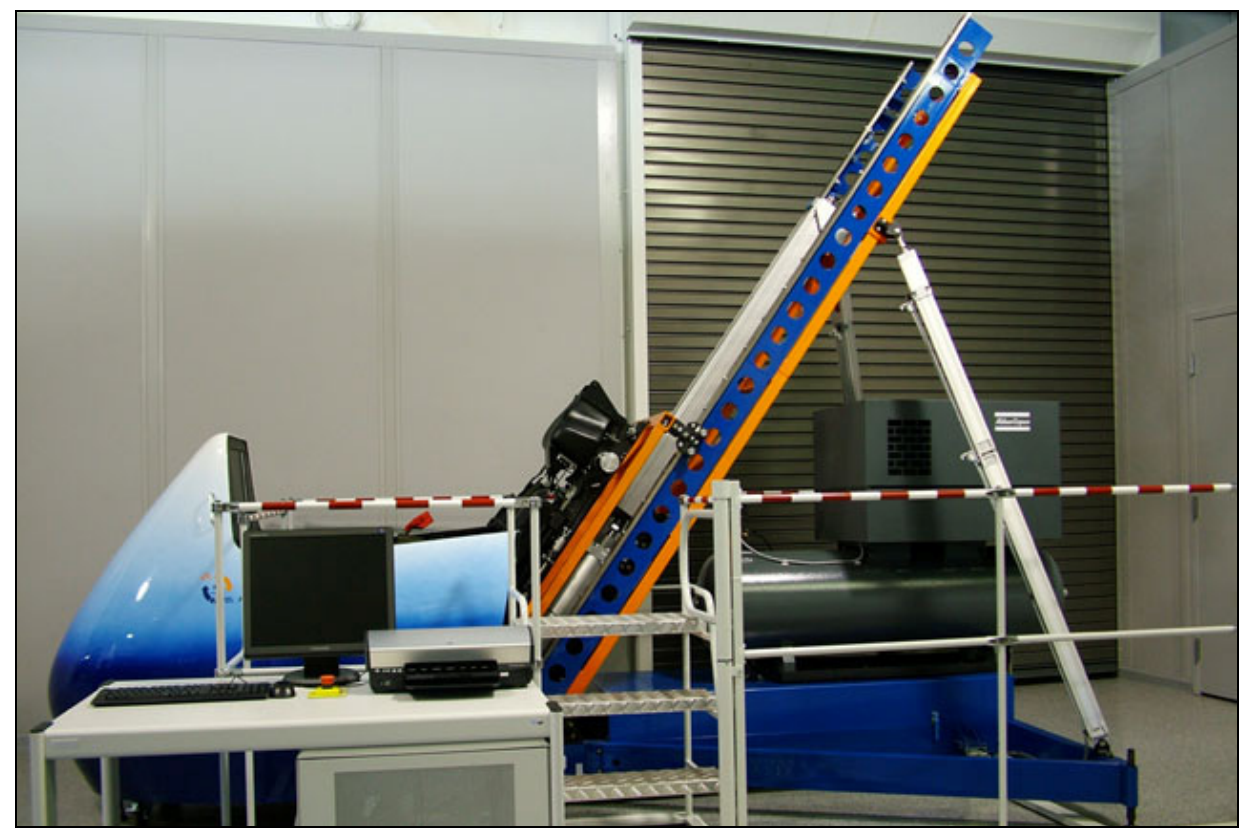

Figure 3 - Ejection seat trainer

Puc. 3 - Симуляционное катапультируемое кресло Слика 3 - Симулатор избацивог седишта

Horizontal straps with rocket sleds that can be stopped by special mechanisms are used to study the effects of line speed reduction, similar to those that occur in car or aircraft accidents (Harris, Piersol, 1988). 


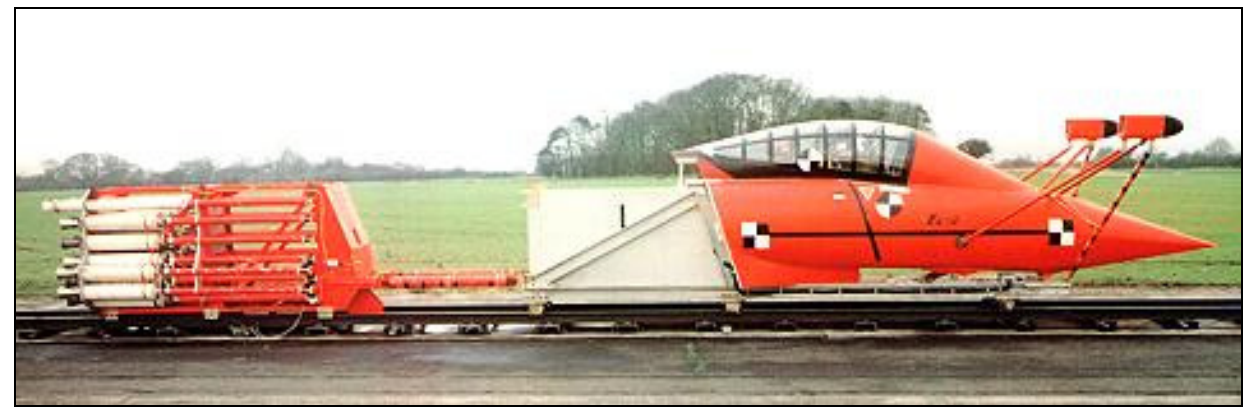

Figure 4 - Martin Baker Eurofighter rocket sled

Puc. 4 - Ракетные сани Мартин Бейкер для моделирования разгона самолета Eurofighter

Слика 4 - Ракетне санке Martin Baker за симулацију убрзања на авиону Eurofighter

Studies involving a combination of acceleration and vibrations are carried out by mounting an oscillator on the centrifuge. Exhaust pipes, sirens and respirators are used to study the reaction of the body to the distribution of pressure around it.

\section{Simulation of the human body}

Determining the sensitivity threshold in humans to mechanical forces and explaining injuries that occur when these limits are exceeded often require experimenting at various levels of potential hazards. In order to avoid unnecessary risks to humans, animals were used first for detailed physiological studies. These studies have resulted in determining the levels wich are, with reasonable probability, safe for humans. However, these comparative experiments have obvious limitations. Different structures, sizes and weights of most animals move their curve of the threshold of sensitivity to mechanical forces into other frequency bands, different from those observed in humans. Both generally and partly known physiological differences between species should be taken into account. For example, the natural frequency of the thorax-abdomen system of a human subject is between 3 and $4 \mathrm{~Hz}$, while in mice the same resonance occurs between 18 and $25 \mathrm{~Hz}$. Accordingly, the maximum effect and maximum damage occur at different frequencies of vibration and different models of shock time in mice and in humans. Dogs, pigs and primates are used in large numbers in these tests (Harris, Piersol, 2002). 


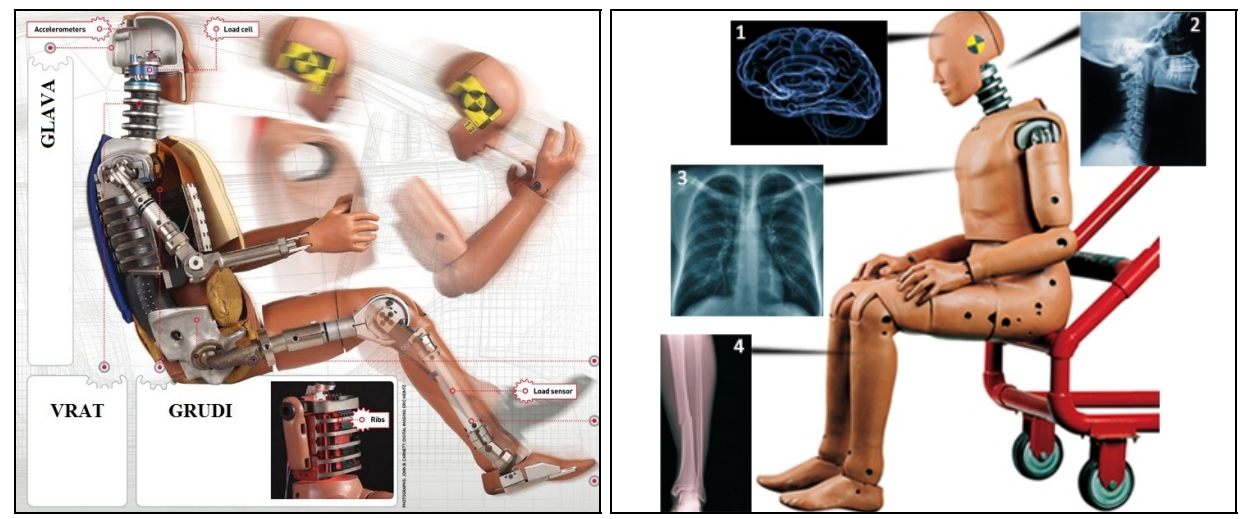

Figure 5- Hybrid III dummy - doll designed for use in frontal motor vehicle crash tests Puc. 5 - Hybrid III dummy - антропометрический манекен для краш-тестов на лобовое столкновение

Слика 5 - Hybrid III dummy - лутка намењена за употребу у тестовима чеоног судара моторних возила

A lot of kinetic processes, physical load, and total destructive anatomical effects can be studied on dummies similar to people in size, shape, mobility, overall weight and weight distribution in the body. Unlike those used only for the purposes of load testing, dummies that simulate the basic static and dynamic properties of the human body are called "anthropometric" or "anthropomorphic" dummies. They are widely used in the study of plane and car crashes (North Atlantic Treaty Organization, 1996).

In the case of a frontal car crash, a Hybrid III dummy is used, which has become the standard in North America and Europe to simulate the behavior of passengers in crash tests and safety-related tests (Figures 5 and 7 ). The original dummy is designed to match $50 \%$ of the population of North American men. It has a metal "skeleton" covered with vinyl leather and wool, with a rubber lumbar spine which can bend to mimic the seated position and a shoulder structure capable of withstanding the load of a seat belt. In other studies, dummies are used instead humans for the evaluation of protective seats and belts. An attempt was made to achieve the same "elasticity" of the human tissue by applying some kind of filling in such dummies. However, these are rough simulations at best, and their dynamic properties are generally, if at all, only reasonably coordinated in a very narrow range of low frequencies. This feature, together with the passivity of these dummies, makes an important mechanical difference between them and the humans. 

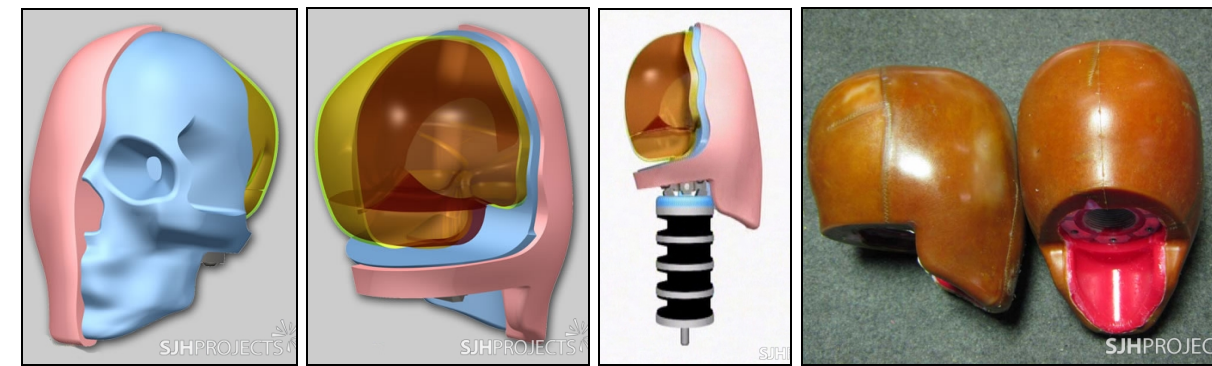

Figure 6 - Frangible Surrogate Headform: a) front view, b) view from behind, c) head on the neck of the Hybrid III dummy, d) Completed Frangible Surrogate Headform

Puc. 6 - Голова антропометрического манекена: а) вид спереди, б) вид сзади, с) голова на шее Hybrid III dummy, d) общий вид головы антропометрического манекена

Слика 6 - Ломљива сурогат глава: а) поглед спреда, б) поглед отпозади, ц) глава на врату Hybrid III dummy, д) коначни облик ломљиве сурогат главе

Efforts have been made to simulate the mechanical properties of the human head in order to study the physical phenomena that occur in the brain in crash conditions. Although these forms only look like the human head, they are very useful in assessing the protective characteristics of helmets during crash conditions. Plastic heads, adapted to the standard dimensions of the head, are designed to "burst" under the same energy under which a human head "bursts". They are made of skulls and simulated brain mass (a mixture of glycerin, ethylene glycol, etc.). The static properties of the skin and the tissue of the scalp are simulated by polyvinyl foam (Harris, Piersol, 2002).

The SKJH Project - Blast Protection Specialists company produces surrogate human body parts, such as the lower limbs and heads, for explosive and ballistic testings. Figure 6 shows a frangible surrogate head (frangible Surrogate Headform - FSH), made by NATO technology under the influence of ballistic and forensic investigations conducted by the Discovery Channel about the assassination of President Kennedy. The different layers of the head are modelled in one unit that simulates the human skull (www.sjhprojects.com). 


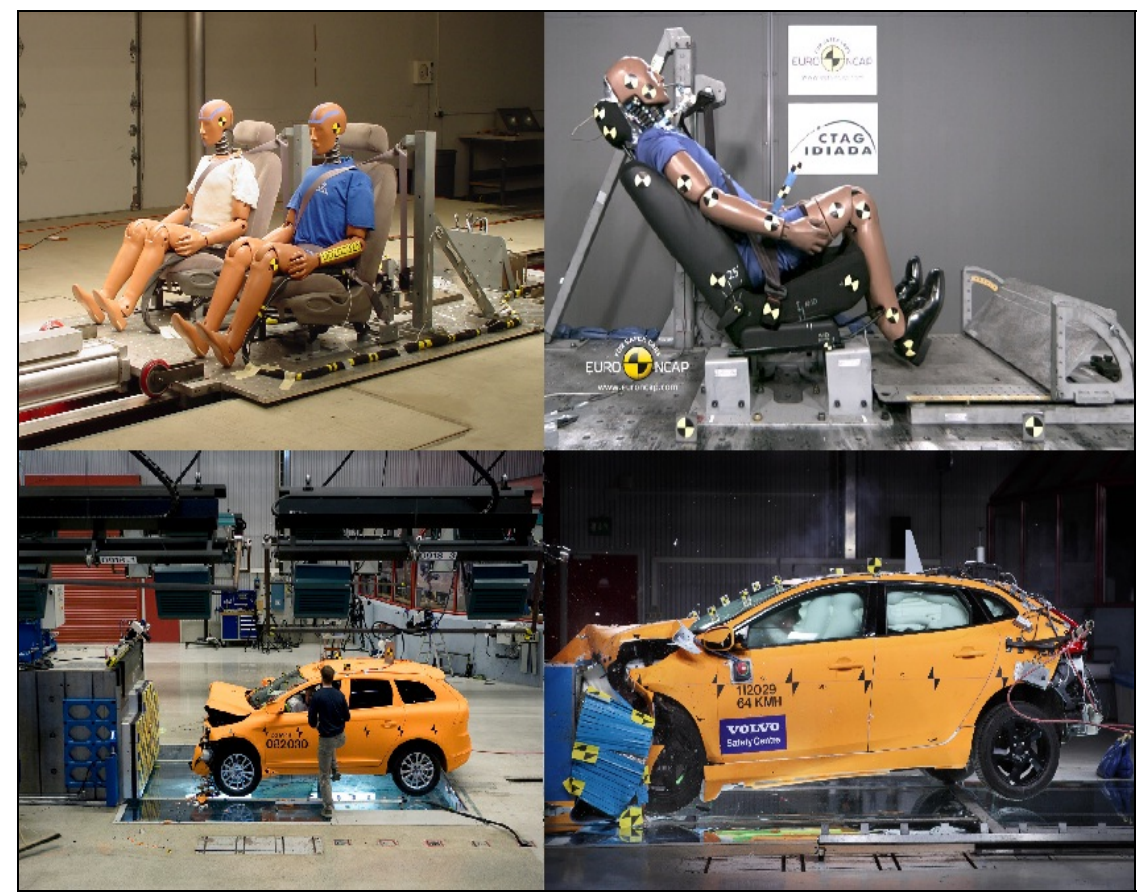
I A Institute, together with its partners, has developed a neck for hybrid dummies to be used in crash tests in order to better present injuries that occur in racing car drivers. The advantage of this neck is a possibility of its elongation (www.aimss.com.au).

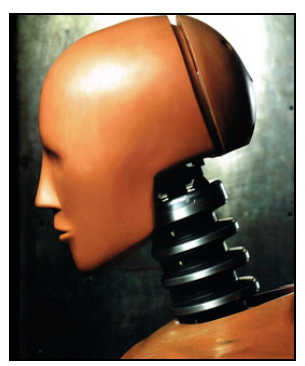

Figure 8 - Neck for crash-test dummies

Puc. 8 - Шея манекенов, используемых в дорожно-транспортных краш-тестах Слика 8 - Врат за лутке које се користе при тестирању саобраћајних несрећа 


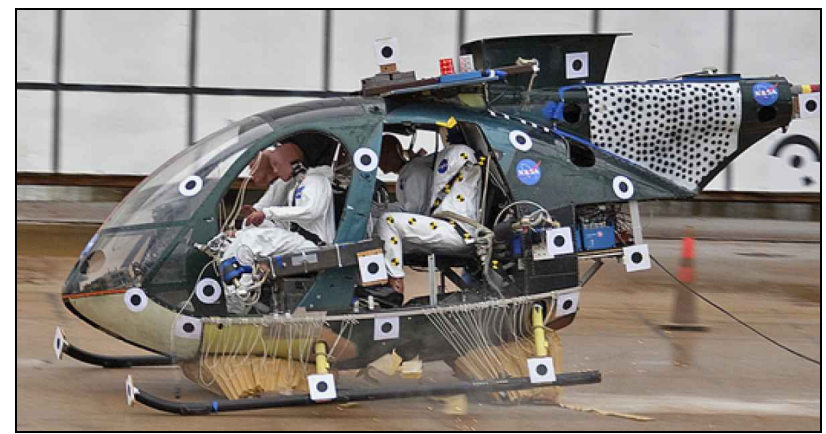

Figure 9 - Crash-test of a helicopter MD-500 with a crew of four anthropometric dummies - Hybrid III dummies

Puc. 9 - Краш-тест вертолета MD-500 с экипажем из четырех антропометрических Hybrid III манекенов

Слика 9 - Тестирање удеса хеликоптера МД-500 са посадом од четири антропометричке лутке Hybrid III dummy

\section{Physical characteristics of the human body}

Simple mechanical systems such as the one shown in Figure 10 for a standing man are often sufficient to describe and understand the important features of the reactions of the human body to low-frequency vibrations.

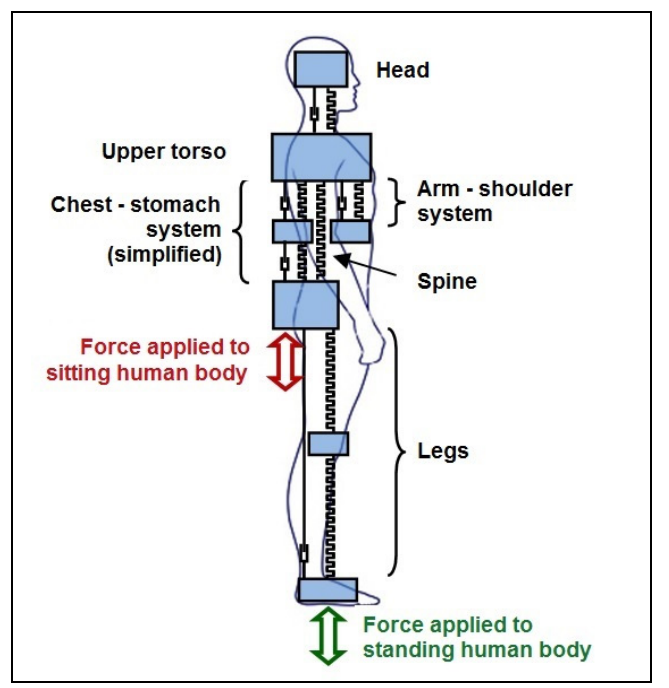

Figure 10 - Simplified mechanical system representing the human body Puc. 10 - Упрощенная механическая система человеческого организма Слика 10 - Поједностављени механички систем људског тела 


\section{Protection against sudden acceleration}

Various studies about car and plane accidents involving experiments with dummies as well as those with living beings show that the full support of the body and limiting the movement of the limbs provide maximum protection from the forces of acceleration and give the best chances of survival. If the subject is restrained in the seat, he is protected from moving around which would cause injuries, because the subject could come into contact with the inner surfaces of the cabin. The load due to the reduction rate should be distributed over the whole body in order to avoid the concentration of forces which leads to bending and shearing effects. The load should be transferred as directly as possible to the skeleton, to the pelvic structure most preferrably - not via the spine. Theoretically, a rigid layer around the body will protect it to the maximum by preventing deformation. A body fixed to a rigid seat approximates such a condition; opposing to longitudinal acceleration, a part of the load on the shoulders and arms is shifted from the spinal column to the seat back. Arm rests can remove the load from the shoulders to the arms.

There have been many attempts to incorporate energy absorbing devices, either into harnesses or into a seat, with the intention to change the time of acceleration so as to limit the greatest acceleration. For example, imagine an aircraft stopped in the event of a crash at a speed of $161 \mathrm{~km} / \mathrm{h}$ at a distance of $17 \mathrm{~m}$ - it is subjected to a deceleration of $67 \mathrm{~g}$. An energy-absorbing device designed to be stretched to $17 \mathrm{~g}$ would require a displacement of $48 \mathrm{~cm}$. While traveling over this distance, the body or the seat would be, in relation to the aircraft, slowing by a force of $14.4 \mathrm{~g}$ and would have a top speed of $11 \mathrm{~m} / \mathrm{s}$, depending on the structure of the aircraft. At this speed, a human head strikes a surface (e.g. cabin interior) by force many times stronger than the minimum required to cause fracture of the skull. Therefore, this principle of energy absorption requires that special attention be paid to the available space for the seat and passengers in the aircraft design. Seats for jet aircraft are designed to have mechanisms for the absorption of energy in the form of rear retractable legs. The maximum displacement of such seats is $15 \mathrm{~cm}$. Such seats are designed to start moving between $9 \mathrm{~g}$ and $12 \mathrm{~g}$ of horizontal load, depending on the floor strength. During displacement, the legs are moving at the floor level which is considered useful if the floor wrinkles in a crash. Theoretically, such a seat can be exposed to a deceleration of $30 \mathrm{~g}$ for $0.037 \mathrm{~s}$ or $20 \mathrm{~g}$ for $0.067 \mathrm{~s}$ without transmitting deceleration over $9 \mathrm{~g}$ to the seat itself. However, increasing the exposure time must be taken into consideration as much as the maximum acceleration. Figure 11 shows a 
seat composed of U-shaped front and rear leg members joined in an Xshaped configuration, which allows their controlled deformation in a crash situation, i.e. they bend forwards thus lowering the centre of gravity (www.google.com/patents/ep0256749a2).
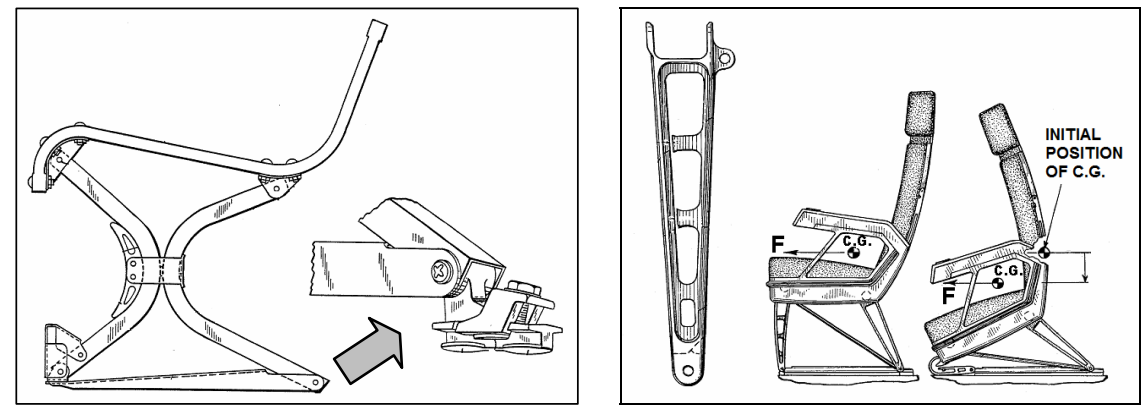

Figure 11 - Seats with energy-absorbing mechanisms

Puc. 11 - Сиденья с механизмами поглащающими энергию удара

Слика 11 - Седишта са механизмима за апсорпцију енергије

Another way to absorb energy is the plastic deformation of the front seat legs (Figure 11), when the seat moves forwards and downwards thus lowering the center of gravity (www.google.com/patents/us4440441).

Considering that the human body with good support has a high sensitivity threshold to deceleration force, seats and floors in aircraft and other vehicles, including the entire interior that surrounds the crew and passengers, should be designed to withstand deceleration in a crash of nearly $40 \mathrm{~g}$, depending on weight and space limitations. Parts of the structures that surround the cabin should be arranged so that their crushing or mashing reduces forces that act on the inside. Any pointed objects or easily loosened objects inside the aircraft should be avoided. To obtain the best chance of survival, seats should be exposed to a dynamic load of pressure of $20 \mathrm{~g}-40 \mathrm{~g}$. The Civil Aviation Regulations require a minimum static load of $9 \mathrm{~g}$. The method for assessing seat shockresistance at sudden decelerations of the aircraft, with the survival of passengers or the crew, can also be applied in the case of seats of conventional design. It was found out that a passenger facing opposite to the direction of motion is more likely to survive sudden deceleration in a crash since in this case the impact force is more evenly distributed on the body. Neck injuries must be prevented by proper head supports. As opposed to the driving on a train or in a car, driving disadvantages in this position on a plane are minimal because there is no movement of objects in the direct field of view of passengers, which could hurt him. Also, with 
seats facing backwards, the center of passenger support during deceleration is approximately $30 \mathrm{~cm}$ above the point where the seat belt would be attached for forward facing travelers. It follows that the seat facing backwards is subject to a greater tilting and bending, i.e. if two seats are of the same weight, the one facing the direction of motion will withstand higher loads without breaking in a crash. The seat facing the opposite direction will have only approximately half of the anticipated strength of a seat facing the direction of motion and about $1 / 3$ of its own frequency (Harris, Piersol, 2002).

Safety increase in aircraft and automobile crashes can be achieved by spreading the load of impact over a larger area of the body and fixing the body more rigidly to the seat. Shoulder belts, thigh belts, chest belts and arm holders are additional support for the body as shown in Figure 12. In airplane crashes, vertical and horizontal loads must be anticipated, while in car accidents horizontal loads are most likely to occur.

Safety belts or seats are used to limit the displacement of people in aircraft or vehicles and to prevent overturning of passengers on board or their falling out. Their effectiveness has been repeatedly proven in laboratory tests and actual crashes.

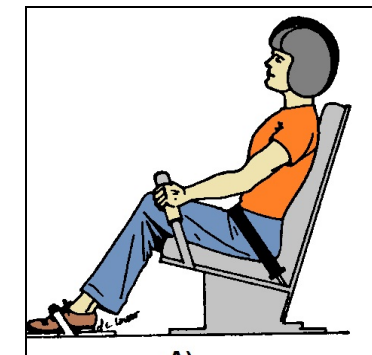

A)

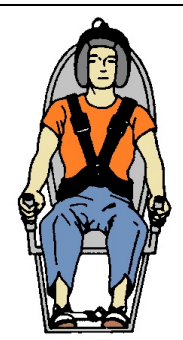

B)

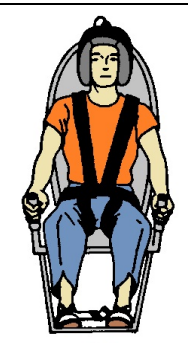

C)

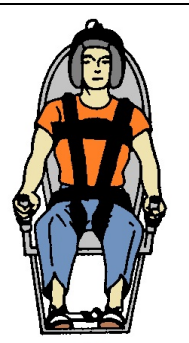

D)

Figure 12 - Protective harnesses for rapid accelerations or decelerations. The following devices were evaluated in sled deceleration tests: (A) Seat belt for automobiles and commercial aviation (B) Standard military lap and shoulder strap (C) Like (B) but with thigh straps added to prevent head- ward rotation of the lap strap (D) Like (C) but with chest strap added

Puc. 12 - Защитные системы на случай внезапного разгона или замедления. Следующие устройства прошли испытания внезапного замедления:

А) автомобильные и авиационные ремни безопасности, В) Стандартная военная Ременно-Плечевая Система: ремень через плечо, С) аналогично В), с дополнительными ремнями по бедрам D) аналогично C) с дополнительным ремнем через грудь.

Слика 12 - Заштитни системи за нагло убрзавање или смањење брзине. Следећи уређаји процењени су у тестовима са успоравајућим санкама: A) сигурносни појас за аутомобиле и комерцијалну авијацију, Б) стандардни војни систем појаса са каишевима преко рамена, Ц) попут Б) али са појасевима преко бутина,

Д) попут Ц) али са додатим каишом преко груди 
In a sudden decrease of speed, a traveler facing the direction of motion and wearing a seatbelt comes into contact with the inner surfaces of aircraft or vehicle; his hands, feet and upper torso bend forwards until his chest hits his knees or until the body is stopped by hitting other objects (back of the seat in front, cabin wall, dashboard, steering wheel, gear stick, Figures 13 and 14). Since reducing the longitudinal acceleration from $18 \mathrm{~g}$ to $15 \mathrm{~g}$ may result in 3 times higher acceleration of the chest hitting the knees, this load seems to be a limit that the human body can tolerate with a seat belt alone. Approximately the same limit is obtained when the headneck structure is considered.

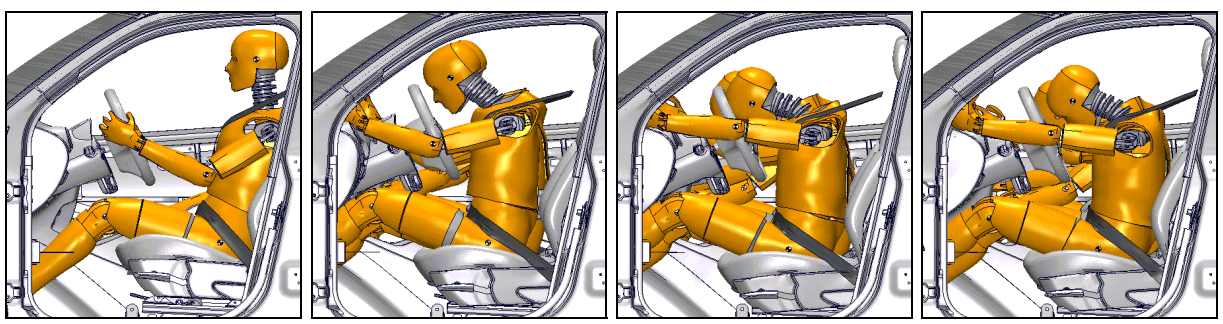

Figure 13 - Animation of a frontal impact test

Puc. 13 - Анимация лобового столкновения

Слика 13 - Анимација чеоног судара

The efficiency of adequately made shoulder and chest belts in car crashes is shown in Figure 14. The belt across the upper part of the stomach should be tight just enough to provide comfort without being loose. When the body moves forwards, about $60 \%$ of its mass is retained by the belt and it represents the belt load. If the upper torso is fixed to the back of the seat by any type of harnesses (shoulder harness, chest belt and the like), the seat load is approximately the same for the front seats and the ones behind them. As far as the threshold of sensitivity of the body in a crash is concerned, there is no difference between these seats. These body restraints for passengers and crews must be applied without creating excessive discomfort.

Airbags in front of the driver, and often the front passenger, which inflate in the event of a frontal crash, have been installed in most vehicles during the last ten years. While initially considered as an alternative for passive seatbelts in case passengers do not wear them, airbags are today most useful when used together with shoulder and chest safety belts. The device in the airbag system contains impact sensors, set at the front of the vehicle. They send signals about speed changes to the control device; changes over $22 \mathrm{~km} / \mathrm{h}$ cause a pyrotechnic reaction in which a generated gas inflates a bag of porous fabric, usually at $25 \mathrm{~m} / \mathrm{s}$, so that the bag inflates enough to distribute the deceleration forces over a large surface 
area on contact with the occupant. Accident data collected between 1990 and 1997 in the United States have shown that while airbags do save lives (about 2,620 people), they were also responsible for the deaths of at least 44 children and 36 adults during this period (Phen et al, 1998). Most of the deaths have been attributed to the size and position of the passenger at the time of impact with the airbag. If a passenger is not fixed by the seat belt, the airbag may impact the occupant with sufficient force to cause fatal injuries (Harris, Piersol, 2002).

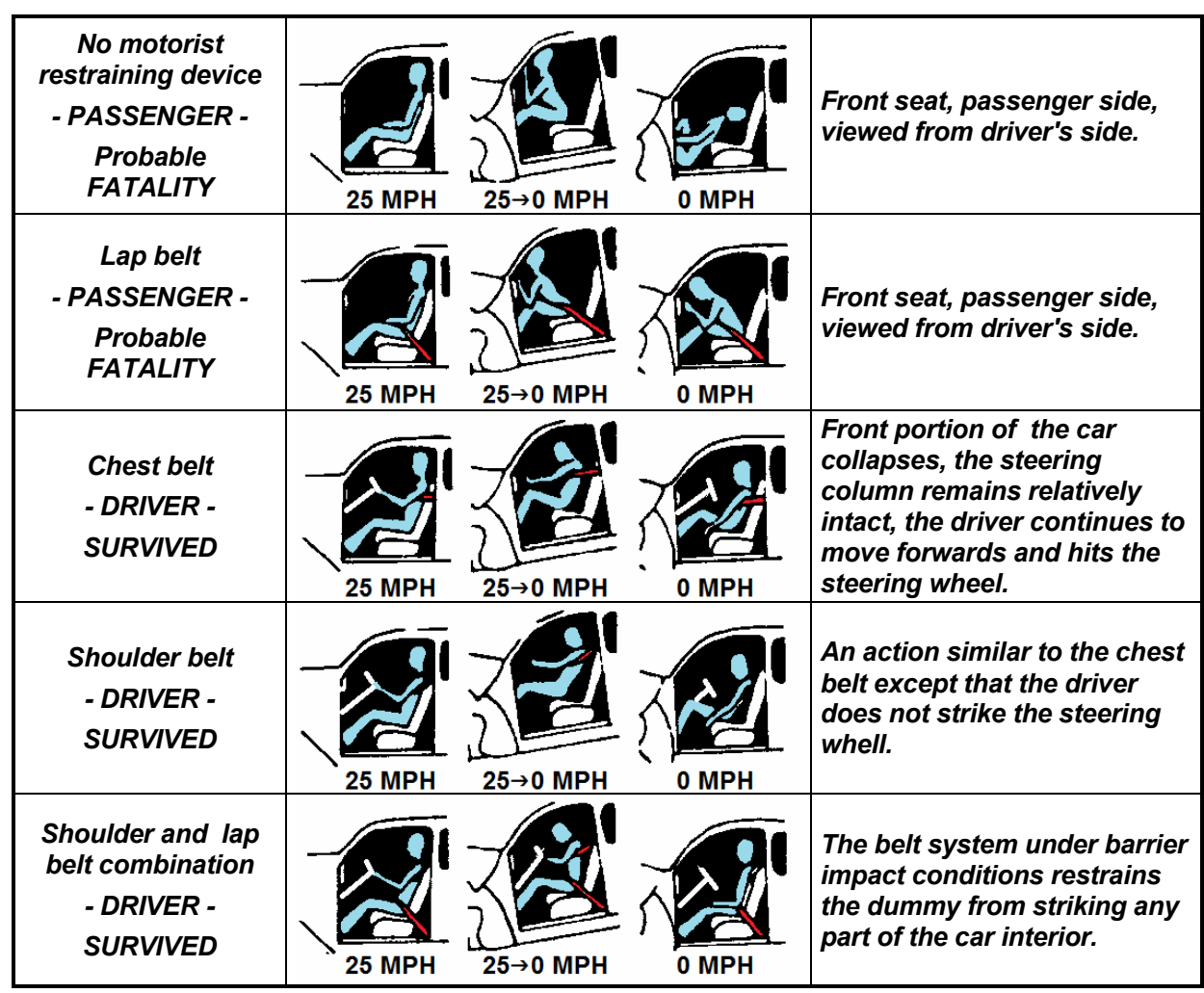

Figure 14 - Effects of varying safety-belt arrangements on the driver and the passenger in a $25-\mathrm{mph}$ automobile collision with a fixed barrier $(40 \mathrm{~km} / \mathrm{h})$.

Puc. 14 - Эффрект различных систем ремней безопасности на безопасность водителя и пассажиров при наезде автомобиля на неподвижный стационарный объект на скорости $25 \mathrm{mph}(40 \mathrm{~km} / 4)$

Слика 14 - Утицај различитих система сигурносних појасева на возача и сувозача приликом судара аутомобила са фриксном препреком при брзини од $25 \mathrm{mph}(40 \mathrm{~km} / \mathrm{h})$. 
The dynamic properties of seat cushions are extremely important if acceleration force is applied through the cushion to the body. This problem is especially studied for cushions used in ejection seats. The seat cushion is almost ideal if, during its compression under static load, it spreads the load uniformly over a wide area of the body and if it compesses almost completely under the average weight. Slow-reacting plastic foam such as honeycomb polyurethane foam of a thickness of $5 \div 6.5 \mathrm{~cm}$ meets these requirements.

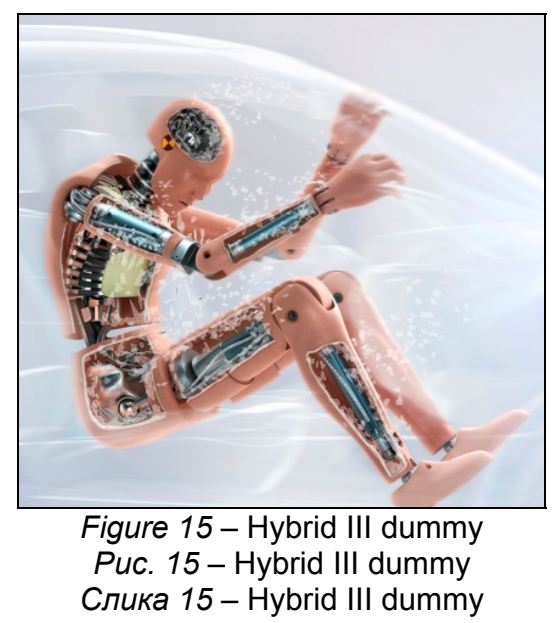

Body acceleration just before impact is an important factor of the threshold of the sensitivity of the human body on impact. The so-called dynamic overload consists of an imposed acceleration which precedes or occurs simultaneously and in the same direction with the impact acceleration. For example, dynamic overload occurs when the driver brakes the car before it hits a barrier. Experiments show that this phenomenon reduces the acceleration of body parts at impact, and therefore potentially reduces adverse health effects. Dynamic load should not be confused with static load originating from seatbelts.

\section{Conclusion}

The mechanical properties of the man as a very complex mechanical system are often subject to change. The existing knowledge about the minimum forces that can cause injury to the human body is incomplete and inaccurate. Most of the quantitative research on the effect of impact and 
vibration on humans is conducted in laboratories under controlled simulated conditions. The need for the study of physical, physiological and psychological reactions of living beings in laboratories, under controlled conditions, has led to the development and use of specialized devices for a simulation of impact and vibration in order to carry out experiments on humans and animals.

Many kinematic processes, physical load, and destructive anatomical effects can be studied on dummies which approximate a human being in size, form, mobility, total weight, and weight distribution in body segments. "Anthropometric" or "anthropomorphic" dummies simulate the basic static and dynamic properties of the human body, as opposed to those that are used only for load tests. These dummies are widely used in the study of plane and car crashes. For specific simulations, several types of these dummies have been designed. For example, the Hybrid III dummy is used in studies of frontal car crashes to simulate the behavior of passengers.

Finally, the results of research of automotive and aviation accidents, as well as experiments with dummies, have shown that adequate support for the body and limiting the movement of the limbs provide maximum protection from the forces of acceleration and give the best chance of survival.

\section{References}

Energy absorbing aircraft seat frame structure. Retrieved from www.google.com/patents/EP0256749A2

Energy attenuating seat and leg therefor. Retrieved from www.google.com/patents/US4440441

Harris, C.M., \& Piersol, A.G. 1988. Harris' shock and vibration handbook, 3rd ed.New York: McGraw-Hill Book Company.

Harris, C.M., \& Piersol, A.G. 2002. Harris' shock and vibration handbook, 5th ed.New York: McGraw-Hill.

North Atlantic Treaty Organization. 1996. Anthropomorphic Dummies for Crash and Escape System Testing AGARD-AR-330.Neuilly Sur Seine, France.

Phen, R.L., Dowdy, M.W., Ebbeler, D.H., Kim, E.H., Moore, N.R., and VanZandt, T.R., 1998. Advanced Air Bag Technology Assessment-Final Report, JPL Publications 98-3, Jet Propulsion Laboratory, California Institute of Technology, Pasadena, Calif.

www.sjhprojects.com

www.aimss.com.au 


\section{ИССЛЕДОВАНИЕ ВЛИЯНИЯ УДАРОВ И ВИБРАЦИЙ НА} ЧЕЛОВЕЧЕСКИЙ ОРГАНИЗМ

\section{Зоран Ц. Петрович}

Вооруженные силы Республики Сербия, РВ ПВО, 204-ая военновоздушная бригада, Батайница, Республика Сербия

ОБЛАСТЬ: машиностроение, механика

ВИД СТАТЬИ: обзорная статья

ЯЗЫК СТАТЬИ: английский

\section{Резюме:}

На сегодняшний день имеется недостаточно достоверной информации о силах, которые приводят к различным травмам пассажиров. В частности, трудно получить достоверные данные о влиянии механических сил и о субъективной реакции на эти силы, в основном из-за широкого разнообразия человеческого организма, как в фиизическом смысле, так и в отношении их реакции. Необходимость лабораторного изучения фризических, фризиологических и психологических реакций живых существ в контролируемых условиях способствовала развитию и применению широкого спектра специализированнных устройств для моделирования ударов, столкновений и вибраций, используемых в экспериментах на людях $и$ животных. Антропометрические или антропоморфнные манекены, имитирующие основные статические и динамические качества человеческого тела, широко используются в исследованиях авиационных и автомобильных аварий. Так, например, гибридный манекен, Hybrid III dummy, употребляют в случае лобового столкновения автомобилей. Разнообразные исследования автомобильных и авиационных аварий, а также опыты с манекенами и живыми существами показывают, что устойчивое фриксированное положение тела и ограничение подвижности конечностей обеспечивают максимальную защиту от силы разгона и дают большие шансы на выживание.

Ключевые слова: антропометрический манекен, авария, человеческое тело, вибрации, столкновение, самолет, несчастный случай, автомобиль. 


\section{ИСТРАЖИВАҢЕ УТИЦАЈА УДАРА И ВИБРАЦИЈА НА ЉУДСКО ТЕЛО}

\section{Зоран Ц. Петровић}

Војска Србије, РВ и ПВО, 204. ваздухопловна бригада, Батајница,

Република Србија

ОБЛАСТ: механика, машинство

ВРСТА ЧЛАНКА: прегледни чланак

ЈЕЗИК ЧЛАНКА: енгЛескИ

\section{Сажетак:}

О силама које су потребне да изазову повреде на људском телу постоји врло мало поузданих инфоормација. Наиме, веома је тешко доћи до поузданих података о утицају механичких сила и о субјективној реакцији на ове силе, углавном због комплексности и разноликости људског тела, како у фризичком смислу, тако и у погледу понашања. Потреба за проучавањем фризичких, фризиолошких и психолошких реакција живих бића у лабораторији, под контролисаним условима, довела је до развоја и употребе широког спектра специјализованих уређаја за симулацију удара и вибрација за експерименте на људима и животињама. „Антропометричке” или „антропоморфоне” лутке, које симулирају основне статичке и динамичке особине људског тела, увелико се користе у истраживању авионских и аутомобилских несрећа. Тако, на пример, хибридна лутка, Hybrid III dummу, користи се у случају чеоног аутомобилског судара. Разна истраживања аутомобилских и ваздухопловних незгода, као и експерименти са луткама и живим бићима, показују да потпуна потпора тела и ограничење кретања екстремитета обезбеђују максималну заштиту од сила убрзања.

Кључне речи: антропометричка лутка, удес, људско тело, вибрације, удар, авион, несрећа, аутомобил.

Paper received on / Дата получения работы / Датум пријема чланка: 18. 08. 2015. Manuscript corrections submitted on / Дата получения исправленной версии работы / Датум достављања исправки рукописа: 28. 03. 2016.

Paper accepted for publishing on / Дата окончательного согласования работы / Датум коначног прихватања чланка за објављивање: 01. 04. 2016.

(c) 2017 The Author. Published by Vojnotehnički glasnik / Military Technical Courier (www.vtg.mod.gov.rs, втг.мо.упр.срб). This article is an open access article distributed under the terms and conditions of the Creative Commons Attribution license (http://creativecommons.org/licenses/by/3.0/rs/). 
(С) 2017 Автор. Опубликовано в «Военно-технический вестник / Vojnotehnički glasnik / Military Technical Courier» (www.vtg.mod.gov.rs, втг.мо.упр.срб). Данная статья в открытом доступе и распространяется в соответствии с лицензией «Creative Commons» (http://creativecommons.org/licenses/by/3.0/rs/).

(C) 2017 Аутор. Објавио Војнотехнички гласник / Vojnotehnički glasnik / Military Technical Courier (www.vtg.mod.gov.rs, втг.мо.упр.срб). Ово је чланак отвореног приступа и дистрибуира се у складу са Creative Commons licencom (http://creativecommons.org/licenses/by/3.0/rs/). 